\title{
Prosedur Pengelolaan Keuangan pada Dinas Pemuda, Olahraga, Kebudayaan dan Pariwisata Kabupaten Kapuas
}

\author{
Vivi Pancasari Kusumawardani \\ Dosen Sekolah Tinggi Ilmu Ekonomi YBPK Palangkaraya
}

\begin{abstract}
This study aims to determine the procedure for managing financial statements at the Kapuas District Office of Youth, Sports, Culture and Tourism.

The data used in this study are documentary data, while the data sources used are secondary data with data collection technique in the form of documentation technique, namely collecting written material in the form of data obtained from the Finance Department of the Department of Youth, Sports, Culture and Tourism Kapuas Year 2015 and 2016. Data analysis technique use qualitative analysis technique.

The results showed that: (1) the Kapuas District Youth, Sports, Culture and Tourism Office had financial management procedures as a guideline governing the financial management process that covered all financial aspects managed by the Kapuas District Culture, Youth and Sports Service. (2) In the financial management procedure owned by the Department of Youth, Sports, Culture and Tourism of the Kapuas Regency, it has complied with government regulations stipulated in the Minister of Home Affairs Regulation Number 13 of 2006
\end{abstract}

Keywords : Procedure, SAP

Abstrak

Penelitian ini bertujuan untuk mengetahui prosedur pengelolaan laporan keuangan pada Dinas Pemuda, Olahraga, Kebudayaan dan Pariwisata Kabupaten Kapuas.

Data yang digunakan dalam penelitian ini adalah data dokumenter, sedangkan sumber data yang digunakan adalah data sekunder dengan teknik pengumpulan data berupa teknik dokumentasi yaitu mengumpulkan bahanbahan yang tertulis berupa data-data yang diperoleh dari Bagian Keuangan Dinas Pemuda, Olahraga, Kebudayaan dan Pariwisata Kabupaten Kapuas Tahun 2015 dan 2016.Teknik analisis data menggunakan teknik analisis kualitatif.

Hasil penelitian menunjukkan bahwa : (1) Dinas Pemuda, Olahraga, Kebudayaan dan Pariwisata Kabupaten Kapuas telah memiliki prosedur pengelolaan keuangan sebagai pedoman yang mengatur tentang proses pengelolaan keuangan yang mencakup seluruh aspek keuangan yang dikelola oleh Dinas Kebudayaan, Kepemudaan dan Olahraga Kabupaten Kapuas. (2) Dalam prosedur pengelolaan keuangan yang dimiliki oleh Dinas Pemuda, Olahraga, Kebudayaan dan Pariwisata Kabupaten Kapuas telah memenuhi ketentuan pemerintah yang diatur dalam Peraturan Menteri Dalam Negeri Nomor: 13 Tahun 2006.

Kata Kunci : Prosedur, SAP

\section{PENDAHULUAN}

\section{Latar Belakang}

Pengelolaan keuangan daerah dijabarkan dalam Peraturan Menteri Dalam Negeri Nomor 13 Tahun 2006, Peraturan Menteri Dalam Negeri Nomor 59 Tahun 2007 yang mengatur tentang Pedoman Pengelolaan Keuangan Daerah. Untuk penatausahaan keuangan daerah diatur oleh Peraturan Menteri Dalam Negeri Nomor 55 Tahun 2008. Penatausahaan dan akuntansi keuangan daerah di Indonesia telah banyak mengalami perubahan seiring dengan semangat reformasi manajemen keuangan pemerintah untuk mencapai keberhasilan otonomi daerah. Hal ini ditandai dengan dikeluarkannya paket peraturan perundangan di bidang keuangan negara beserta peraturan-peraturan turunannya yang juga telah banyak mengalami revisi dan penyempurnaan.

Dengan adanya perubahan permendagri, diharapkan akan memberikan kejelasan dan manfaat dalam penatausahaan dan akuntansi. Oleh karena itu, pemerintah daerah perlu beradaptasi dalam mengikuti perubahan tata kelola keuangan daerah. Untuk mengisi kekurangan dan menyempurnakan Permendagri nomor 13 tahun 2006, pada tanggal 26 Oktober 2007, Menteri Dalam Negeri telah menerbitkan Permendagri nomor 59 tahun 2007 tentang perubahan atas Peraturan Menteri Dalam Negeri nomor 13 tahun 2006 tentang Pedoman Pengelolaan Keuangan Daerah. Dalam Permendagri nomor 13 tahun 2006 
pengelolaan keuangan daerah yang diatur meliputi penyusunan rancangan APBD, penetapan APBD, penyusunan dan penetapan APBD bagi daerah yang belum memiliki DPRD, pelaksanaan APBD, perubahan APBD, pengelolaan kas, penatausahaan keuangan daerah, akuntansi keuangan daerah, pertanggungjawaban pelaksanaan APBD, pembinaan dan pengawasan pengelolaan keuangan daerah, kerugian daerah, dan pengelolaan keuangan BLUD.

Dalam penatausahaan dan akuntansi keuangan daerah, secara rinci sistem dan prosedur ditetapkan oleh masing-masing daerah. Perbedaan dimungkinkan terjadi sepanjang hal tersebut tidak bertentangan dengan peraturan pemerintah. Dengan upaya tersebut, diharapkan daerah didorong untuk lebih tanggap, kreatif dan mampu mengambil inisiatif dalam perbaikan dan pembaharuan dalam sistem dan prosedurnya serta meninjau kembali sistem tersebut secara terusmenerus berdasarkan keadaan, kebutuhan dan kemampuan setempat. Dalam penatausahaan dan akuntansi keuangan daerah, pemerintah daerah dapat menggunakan sistem yang disarankan oleh pemerintah sesuai kebutuhan dan kondisinya, dengan tetap memperhatikan standar dan pedoman yang ditetapkan. Di samping itu, dalam pelaksanaan desentralisasi kewenangan pemerintahan kepala daerah, aparatur dan masyarakat berkewajiban untuk tetap menjaga kesatuan bangsa, dan harus melaksanakan tugasnya secara profesional dan bertanggungjawab dalam menyelenggarakan tugas pemerintahan dan pembangunan (La Ode Hasiara, 2009:2). Oleh sebab itu, untuk mengelola keuangan yang baik maka dibutuhkan pemahaman dan praktek yang baik dalam melaksanakan peraturan yang berlaku.

\section{TINJAUAN PUSTAKA}

\section{Pengertian Prosedur}

Prosedur merupakan rangkaian langkah yang dilaksanakan untuk menyelesaikan kegiatan atau aktivitas, sehingga dapat tercapai tujuan yang diharapkan serta dapat dengan mudah menyelesaikan suatu masalah yang terperinci menurut waktu yang telah ditentukan. Pengertian prosedur, salah satunya menurut Ardiyos (2004:73) menyatakan: "Prosedur adalah suatu bagian sistem yang merupakan rangkaian tindakan yang menyangkut beberapa orang dalam satu atau beberapa bagian yang ditetapkan untuk menjamin agar suatu kegiatan usaha atau transaksi dapat terjadi berulangkali dan dilaksanakan secara seragam".
Fungsi Prosedur

Fungsi prosedur menurut Mulyadi (2013:60)

1. Memperlancar tugas pegawai atau tim atau unit kerja.

2. Sebagai suatu dasar hukum bila terjadi penyimpangan.

3. Mengetahui dengan jelas hambatanhambatannya dan mudah dilacak.

4. Mengarahkan pegawai untuk sama-sama disiplin dalam bekerja.

5. Sebagai pedoman dalam melaksanakan pekerjaan rutin

\section{Tujuan Prosedur}

Sedangkan tujuan prosedur yaitu:

1. Agar pegawai menjaga konsistensi dan tingkat kinerja pegawai atau tim dalam organisasi atau unit kerja.

2. Agar mengetahui dengan jelas peran dan fungsi tiap-tiap posisi dalam organisasi.

3. Memperjelas alur tugas, wewenang dan tanggung jawab dari pegawai terkait.

4. Melindungi organisasi atau unit kerja dan pegawai dari mal praktik atau kesalahan administrasi lainnya.

5. Untuk menghindari kegagalan atau kesalahan, keraguan dan duplikasi.

\section{Pengelolaan Keuangan Daerah}

Menurut pasal 1 ayat 6 Peraturan Pemerintah Republik Indonesia Nomor: 58 Tahun 2005 Tentang Pengelolaan keuangan daerah, pengertian pengelolaan keuangan daerah adalah keseluruhan kegiatan yang meliputi perencanaan, pelaksanaan, penatausahaan, pelaporan, pertanggungjawaban dan pengawasan keuangan daerah.

Menurut Chabib (2010:10), prinsip-prinsip pengelolaan keuangan yang diperlukan untuk mengontrol kebijakan keuangan daerah meliputi:

1. Akuntabilitas;

2. Value for money;

3. Kejujuran dalam mengelola keuangan publik;

4. Transparansi.

\section{Tujuan Pengelolaan Keuangan Daerah}

1. Memberdayakan dan meningkatkan perekonomian daerah.

2. Menciptakan sistem pembiayaan daerah yang adil, proporsional, rasional, transparan, partisipatif, bertanggungjawab, dan pasti.

3. Menciptakan acuan dalam alokasi penerimaan negara dari daerah.

4. Menjadikan pedoman pokok tentang keuangan daerah.

\section{Akuntansi Keuangan Daerah}

Menurut Abdul (2007:42) definisi dari Akuntansi Keuangan daerah adalah proses pengidentifikasian, pengukuran, pencatatan dan pelaporan transaksi ekonomi (keuangan) dari 
entitas pemerintah daerah (kabupaten, kota atau provinsi) yang dijadikan sebagai informasi dalam rangka pengambilan keputusan ekonomi yang diperlukan oleh pihak-pihak eksternal entitas pemerintah daerah (kabupaten, kota atau provinsi). Prosedur Sistem Akuntansi Keuangan Daerah (SAKD) menurut Kepmendagri No. 29 Tahun 2002, meliputi :

1. Pencatatan

2. Penggolongan

3. Pelaporan

Akuntansi merupakan suatu disiplin ilmu sehingga akuntansi memiliki lingkup yang luas. Oleh karena itu, akuntansi dibagi menjadi beberapa bidang berdasarkan pokok bahasan yang dikahi. Apabila pokok bahasan yang dikaji adalah entitas penyusunan laporan keuangan, maka akuntansi terbagi menjadi akuntansi sektor privat dan akuntansi sektor publik atau terbagi menjadi akuntansi komersial, akuntansi pemerintahan (sektor publik) dan sosial. Dilain pihak apabila pokok bahasan yang dikaji adalah pengguna informasi akuntansi, maka akuntansi terbagi menjadi akuntansi manajemen dan akuntansi keuangan. Dalam sistematika ilmu akuntansi, dalam klasifikasi pertama kedudukan akuntansi keuangan daerah adalah dalam akuntansi sektor publik atau dalam akuntansi pemerintahan. Sedangkan dalam klasifikasi kedua, akuntansi keuangan daerah tergolong dalam akuntansi keuangan.

\section{Laporan Keuangan Pemerintah Daerah}

Menurut Peraturan Pemerintah Nomor 24 Tahun 2004 Tentang Standar Akuntansi Pemerintahan(SAP), Pemerintah Daerah dituntut untuk dapat menyajikan laporan keuangan yang meliputi:

\section{Laporan Realisasi Anggaran}

Laporan realisasi anggaran menyajikan ikhtisar sumber, alokasi dan pemakaian sumber daya ekonomi yang dikelola oleh pemerintah daerah yang menggambarkan perbandingan antara anggaran dan realisasinya dalam 1 (satu) periode pelaporan. Unsur yang tercakup dalam laporan realisasi anggaran terdiri dari pendapatan, belanja, transfer dan pembiayaan. Terhadap unsur-unsur tersebut masing-masing didefinisikan sebagai berikut :

a. Pendapatan (basis kas) adalah penerimaan oleh bendahara umum daerah yang menambahkan ekuitas dana lancar dalam periode tahun anggaran bersangkutan yang menjadi hak pemerintah daerah yang di akui sebagai penambah nilai kekayaan bersih.

b. Belanja (basis kas) adalah semua pengeluaran bendahara umum daerah yang mengurai ekuitas dana lancar dalam periode tahun anggaran bersangkutan yang tidak akan diperoleh pembayarannya kembali.

c. Transfer adalah penerimaan/ pengeluaran uang dari suatu entitas pelaporan dari/kepada entitas pelaporan lain, termasuk dana perimbangan dan dana bagi hasil.

d. Pembiayaan (financing) adalah setiap penerimaan yang harus dibayar kembali, baik pada tahun anggaran bersangkutan, maupun tahun-tahun anggaran berikutnya, yang dalam penganggaran pemerintah daerah terutama dimaksudkan untuk penutup devisit atau memanfaatkan surplus anggaran. Penerimaan pembiayaan antara lain dapat berasal dari pinjaman dan hasil divestasi. Pengeluaran pembiayaan antara lain digunakan untuk pembayaran kembali pokok pinjaman, pemberian pinjaman kepada entitas lain dan penyertaan modal pemerintah daerah.

Tabel Laporan Realisasi Anggaran

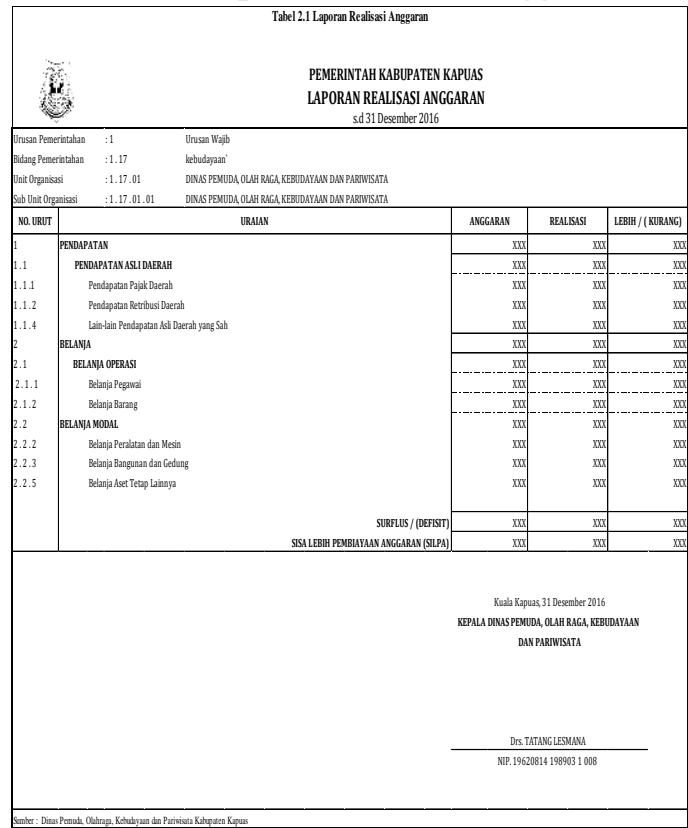

2. Neraca

Neraca menggambarkan posisi keuangan suatu entitas pelaporan mengenai asset, kewajibban dan ekuitas dana pada tanggal tertentu. Neraca sekurang-kurangnya mencantumkan pos-pos berikut :

a. Kas dan setara kas;

b. Investasi jangka pendek;

c. Piutang pajak dan bukan pajak;

d. Persediaan;

e. Investasi jangka panjang;

f. Asset tetap;

g. Kewajiban jangka pendek;

h. Kewajiban jangka panjang;

i. Ekuitas dana 


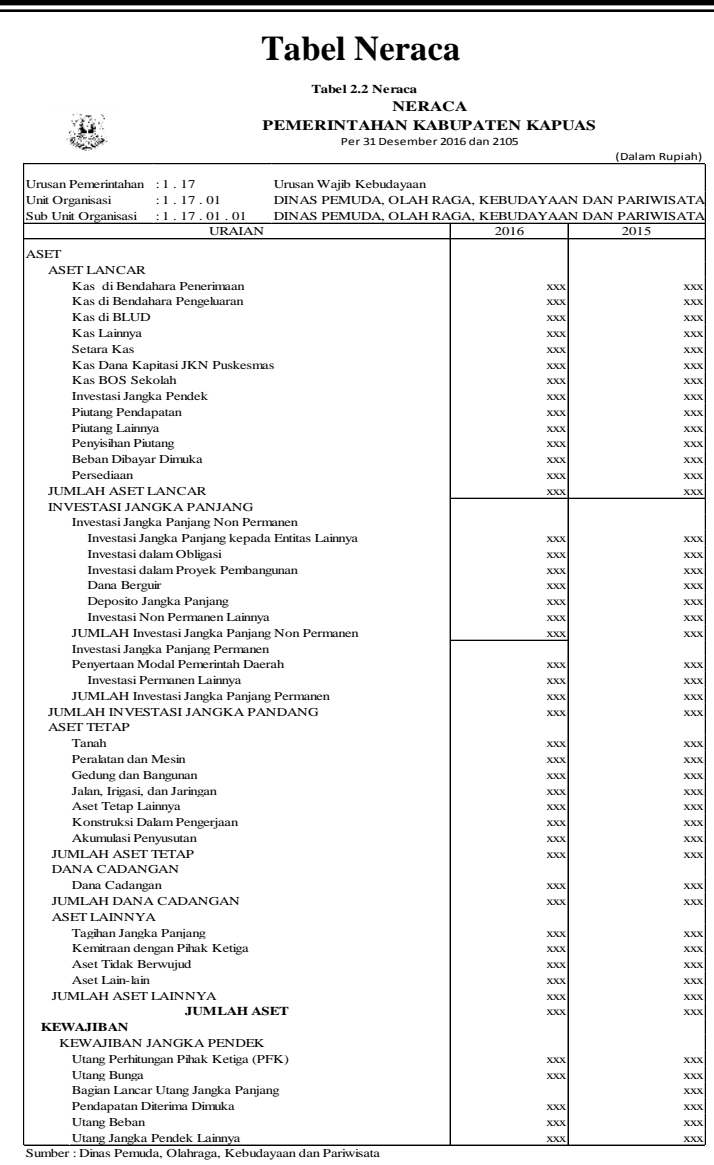

\section{Laporan Arus/ Aliran Kas}

Laporan arus kas menyajikan informasi kas sehubungan dengan aktifitas operasional, investasi asset non keuangan, pembiayaan dan transaksi non anggaran yang menggambarkan saldo awal, penerimaan, pengeluaran dan saldo akhir kas pemerintah daerrah selama periode tertentu. Unsur yang tercakup dalam laporan arus kas terdiri dari penerimaan dan pengeluaran kas, yang masing-masing didefinisikan sebagai berikut :

a. Penerimaan kas adalah semua aliran kas terdiri dari penerimaan yang masuk ke bendahara umum daerah;

b. Pengeluaran kas adalah semua aliran kas yang keluar dari bendahara umum daerah;

\section{Catatan atas Laporan Keuangan}

Catatan atas laporan keuangan berisi penjelasan naratif atau rincian dari angkaangka yang tertera dalam laporan realisasi anggaran, neraca, laporan arus kas. Catatan atas laporan keuangan juga memuat informasi tentang kebijakan akuntansi yang dipergunakan oleh entitas pelaporan dan infaormasi lain yang diharuskan dan dianjurkan untuk diungkapkan di dalam stndar akuntansi pemerintahan serta ungkapanungkapan yang diperlukan untuk menyajikan hasil laporan keuangan secara wajar. Adapan hal-hal yang diungkapkan dalam catatan atas laporan keuangan adalah sebagai berikut :

a. Menyajikan informasi tentang kebijakan fiskal/keuangan ekonomi makro, pencapaian target APBD berikut kendala dan hambatan yang dihadapi dalam pencapaian target;

b. Menyajikan ikhtisar pencapaian kinerja keuangan selama satu tahun pelaporan;

c. Menyajikan informasi tentang dasar penyusunan laporan keuangan dan kebijakan akuntansi yang dipilih untuk diterapkan atas transaksi-transaksi dan kejadian-kejadian penting lainnya;

d. Mengungkapkan informasi yang diharuskan oleh Standar Akuntansi Pemerintahan (SAP) yang belum disajikan pada lembar muka laporan keuangan;

e. Mengungkapkan informasi untuk pos-pos asset dan kewajiban yang timbul sehubungan dengan penerapan basis akrual atas pendapatan, belanja dan rekonsiliasinya dengan basis kas; dan

f. Menyediakan informasi tambahan yang diperlukan untuk penyajian secara wajar, yang tidak disajikan pada lembar muka laporan keuangan.

\section{Standar Akuntasi Pemerintahan}

Standar Akuntansi Pemerintahan (SAP) ditetapkan dengan Peraturan Pemerintah No.71 Tahun 2010 sebagai pengganti Peraturan Pemerintah No.24 Tahun 2005. SAP dinyatakan dalam bentuk Pernyataan Standar Akuntansi Pemerintahan (PSAP), dilengkapi dengan Pengantar Standar Akuntansi Pemerintahan dan disusun mengacu kepada kerangka konseptual akuntansi pemerintahan SAP harus digunakan sebagai acuan dalam menyusun laporan keuangan pemerintah, baik pemerintah pusat maupun pemerintah daerah.

\section{METODE PENELITIAN}

\section{Jenis Penelitian}

Jenis penelitian yang digunakan dalam penelitian ini adalah metode deskriptif, dimana penelitian ini akan menggambarkan fenomena atau karakteristik data yang tengah berlangsung pada saat penelitian ini dilakukan atau selama kurun waktu tertentu untuk menguji dan menjawab pertanyaan mengenai status terakhir dari subyek penelitian. Metode deskriptif memiliki ciri-ciri sebagai berikut:

1. Memusatkan diri pada pemecahan masalahmasalah yang ada pada masa sekarang yang bersifat aktual.

2. Data yang dikumpulkan mula-mula disusun, dijelaskan dan kemudian dianalisis. 
3. Hasil penelitian terhadap masalah-masalah berupa fakta-fakta pada saat ini dari suatu populasi.

\section{Jenis Data}

Jenis data yang digunakan adalah data dokumenter. Menurut Indriantoro dan Supomo (2009:146), data dokumenter adalah jenis data penelitian yang antara lain berupa faktur, jurnal, surat-surat, notulen hasil rapat, memo atau dalam bentuk laporan program. Data dokumenter memuat apa dan kapan suatu kejadian atau transaksi, serta siapa yang terlibat dalam suatu kejadian. Data dokumenter dalam penelitian dapat menjadi bahan atau dasar analisis data yang kompleks yang dikumpulkan melalui metode observasi dan analisis dokumen yang dikenal dengan Content Analysis.

\section{Sumber Data}

Dalam penelitian ini sumber data yang digunakan adalah data sekunder. Pengertian dari data sekunder menurut Indriantoro dan Supomo (2009:146) adalah merupakan data yang diperoleh oleh peneliti secara tidak langsung melalui media perantara. Data sekunder umumnya berupa bukti, catatan atau laporan historis yang telah disusun dalam arsip. Dalam hal ini sumber data yang digunakan adalah laporan keuangan Dinas Pemuda, Olahraga, Kebudayaan dan Pariwisata Kabupaten Kapuas tahun 2016.

\section{Teknik Pengumpulan Data}

Teknik pengumpulan data yang digunakan dalam penelitian ini menggunakan teknik dokumentasi, yaitu mengumpulkan bahan-bahan yang tertulis berupa data-data yang diperoleh dari Bagian Keuangan Dinas Pemuda, Olahraga, Kebudayaan dan Pariwisata Kabupaten Kapuas Tahun 2016.

\section{Teknik Analisis Data}

Teknik analisis data yang digunakan dalam penelitian ini adalah teknik analisis kualitatif, di mana data-data yang berhasil diolah untuk memecahkan masalah penelitian.

Setelah itu penulis menarik kesimpulan dan memberikan saran yang dianggap perlu, sehingga mengumpulkan informasi mengenai Prosedur Pengelolaan Keuangan pada Dinas Pemuda, Olahraga, Kebudayaan dan Pariwisata Kabupaten Kapuas.

\author{
Alat Analisis Data \\ Alat analisis data yang dipakai dalam \\ penelitian ini adalah: \\ 1. Peraturan Pemerintah Nomor 71 Tahun 2010 \\ Tentang Standar Akuntansi Pemerintahan
}

2. Peraturan Menteri Dalam Negeri Nomor: 13 Tahun 2006 Tentang Pedoman Pengelolaan Keuangan Daerah.

\section{HASIL PENELITIAN DAN PEMBAHASAN}

\section{Pendekatan Penyusunan Laporan Keuangan}

Laporan Keuangan Tahun 2016 ini merupakan laporan yang mencakup seluruh aspek keuangan yang dikelola oleh Dinas Kebudayaan, Kepemudaan dan Olahraga Kabupaten Kapuas. Laporan Keuangan ini dihasilkan melalui Sistem Akuntansi Pemerintahan Daerah, yang selanjutnya disingkat SAPD adalah rangkaian sistematik dari prosedur, penyelenggara, peralatan, dan elemen lain untuk mewujudkan fungsi akuntansi sejak analisis transaksi sampai dengan pelaporan keuangan di lingkungan organisasi pemerintahan Kabupaten Kapuas. SAPD dirancang untuk menghasilkan Laporan Keuangan Satuan Kerja yang terdiri dari Laporan Realisasi Anggaran, Neraca, Laporan Operasional, dan Laporan Perubahan Ekuitas.

\section{Basis Akuntansi}

Dinas Kebudayaan, Kepemudaan dan Olahraga Kabupaten Kapuas menerapkan basis akrual dalam penyusunan dan penyajian Neraca, Laporan Operasional, dan Laporan Perubahan Ekuitas serta basis kas untuk penyusunan dan penyajian Laporan Realisasi Anggaran. Basis akrual adalah basis akuntansi yang mengakui pengaruh transaksi dan peristiwa lainnya pada saat transaksi dan peristiwa itu terjadi, tanpa memperhatikan saat kas atau setara kas diterima atau dibayarkan. Sedangkan basis kas adalah basis akuntansi yang yang mengakui pengaruhi transaksi atau peristiwa lainnya pada saat kas atau setara kas diterima atau dibayar. Hal ini sesuai dengan Standar Akuntans Pemenintahan (SAP) yang telah ditetapkan denganPeraturan Pemerintah Nomor 71 Tahun 2010 tentang Standar Akuntansi Pemerintahan.

\section{Dasar Pengukuran}

Pengukuran adalah proses penetapan nilai uang untuk mengakui dan memasukkan setiap pos dalam laporan keuangan. Dasar pengukuran yang diterapkan Dinas Kebudayaan, Kepemudaan dan Olahraga Kabupaten Kapuas dalam penyusunan dan penyajian Laporan Keuangan adalah dengan menggunakan nilai perolehan historis.

Asset dicatat sebesar pengeluaran/penggunaan sumber daya ekonomi atau sebesar nilai wajar dari imbalan yang diberikan untuk memperoleh asset tersebut. Kewajiban dicatat sebesar nilai wajar sumber daya ekonomi yang digunakan pemerintah untuk memenuhi kewajiban yang bersangkutan. 
Pengukuran pos-pos laporan keuangan menggunakan mata uang rupiah. Transaksi yang menggunakan mata uang asing dikonversi terlebih dahulu dan dinyatakan dalam mata uang rupiah.

\section{Kebijakan Akuntansi}

Penyusunan dan penyajian Laporan Keuangan Tahun 2017 telah mengacu pada Standar Akuntansi Pemerintahan (SAP). Kebijakan akuntansi merupakan prinsip-prinsip, dasar-dasar, konvensi konvensi, aturan-aturan, dan praktik-praktik spesifik yang dipilih oleh suatu entitas pelaporan dalam penyusunan dan penyajian laporan keuangan. Kebijakan akuntansi yang diterapkan dalam laporan keuangan ini adalah merupakan kebijakan yang ditetapkan oleh Pemerintah Kabupaten Kapuas yang merupakan entitas pelaporan dari Dinas Kebudayaan, Kepemudaan dan Olahraga Kabupaten Kapuas. Disamping itu, dalam penyusunan telah diterapkan kaidah-kaidah pengelolaan keuangan yang sehat di lingkungan pemerintahan.

Kebijakan-kebijakan akuntansi yang penting yang digunakan dalam penyusunan Laporan Keuangan Dinas Kebudayaan, Kepemudaan dan Olahraga Kabupaten Kapuas adalah sebagai berikut

\section{Pendapatan LRA}

Pendapatan-LRA adalah semua penerimaan Rekening Kas Umum Daerah yang menambah Saldo Anggaran Lebih dalam periode tahun anggaran yang bersangkutan yang menjadi hak pemerintah, dan tidak perlu dibayar kembali oleh pemerintah. Pendapatan-LRA diakui pada saat :

a. Kas atas pendapatan tersebut telah diterima pada RKUD.

b. Kas atas pendapatan tersebut telah diterima oleh Bendahara Penerimaan dan hingga tanggal pelaporan belum disetorkan ke RKUD, dengan ketentuan Bendahara Penerimaan tersebut merupakan bagian dari BUD.

c. Kas atas pendapatan tersebut telah diterima satker/SKPD dan digunakan langsung tanpa disetor ke RKUD, dengan syarat entitas penerima wajib melaporkannya kepada BUD.

d. Kas atas pendapatan yang berasal dari hibah langsung dalam/luar negeri yang digunakan untuk mendanai pengeluaran entitas telah diterima, dengan syarat entitas penerima wajib melaporkannya kepada BUD.

e. Kas atas pendapatan yang diterima entitas lain di luar entitas pemerintah berdasarkan otoritas yang diberikan oleh BUD, dan BUD mengakuinya sebagai pendapatan.

Akuntansi pendapatan-LRA dilaksanakan berdasarkan azas bruto, yaitu dengan membukukan penerimaan bruto, dan tidak mencatat jumlah nettonya (setelah dikompensasikan dengan pengeluaran). Pendapatan-LRA disajikan menurut klasifikasi sumber pendapatan.

2. Pendapatan LO

Pendapatan-LO adałah hak pemerintah daerah yang diakui sebagai penambah ekuitas dalam periode tahun anggaran yang bersangkutan dan tidak perlu dibayar kembali.

Pendapatan-LO diakui pada saat timbulnya hak atas pendapatan dan/atau Pendapatan direalisasi, yaitu adanya aliran masuk sumber daya ekonomi.

Pengakuan Pendapatan-LO diakui bersamaan dengan penerimaan kas selama tahun berjalan dan pada saat penyusunan laporan keuangan.

Akuntansi pendapatan-LO dilaksanakan berdasarkan azas bruto, yaitu dengan membukukan penerimaan bruto, dan tidak mencatat jumlah nettonya (setelah dikompensasikan dengan pengeluaran). Pendapatan disajikan menurut klasifikasi sumber pendapatan.

3. Belanja

Belanja adalah semua pengeluaran dari Rekening Kas Umum Daerah dan Bendahara Pengeluaran yang mengurangi Saldo Anggaran Lebih dalam periode tahun anggaran bersangkutan yang tidak akan diperoleh pembayarannya kembali oleh pemerintah.

Belanja diakui pada saat :

a. Terjadinya pengeluaran dari RKUD.

b. Khusus pengeluaran melalui bendahara pengeluaran pengakuannya terjadi pada saat pertanggungjawaban atas pengeluaran tersebut disahkan oleh unit yang mempunyai fungsi perbendaharaan dengan terbitnya SP2D GU atau SP2D Nihil.

c. Dalam hal badan layanan umum, belanja diakui dengan mengacu pada peraturanperundangan yang mengatur mengenai badan layanan umum.

Belanja disajikan menurut klasifikasi ekonomi/jenis belanja dan selanjutnya klasifikasi berdasarkan organisasi dan fungsi akan diungkapkan dalam Catatan atas Laporan Keuangan.

4. Beban

Beban adalah penurunan manfaat ekonomi atau potensi jasa dalam periode pelaporan yang menurunkan ekuitas, yang dapat berupa pengeluaran atau konsumsi aset atau timbulnya kewajiban.

Beban diakui pada saat timbulnya kewajiban; terjadinya konsumsi asset; terjadinya penurunan manfaat ekonomi atau potensi jasa. Beban disajikan menurut klasifikasi ekonomi/jenis belanja dan selanjutnya 
klasifikasi berdasarkan organisasi dan fungsi diungkapkan dalam Catatan Atas Laporan Keuangan.

5. Aset

Aset diklasifikasikan menjadi Aset Lancar, Aset Tetap, Piutang Jangka Panjang dan Aset Lainnya.

a. Aset Lancar

Aset Lancar mencakup kas dan setara kas yang diharapkan segera untuk direalisasikan, dipakai, atau dimiliki untuk dijual dalam waktu 12 (dua belas) bulan sejak tanggal pelaporan.

Kas disajikan di neraca dengan menggunakan nilai nominal. Kas dalam bentuk valuta asing disajikan di neraca dengan menggunakan kurs tengah Bank Sentral pada tanggal neraca.

Piutang diakui pada saat penyusunan laporan keuangan ketika timbul klaim/hak untuk menagih uang atau manfaat ekonomi lainnya kepada entitas, yaitu pada saat :

1) Terdapat surat ketetapan/dokumen yang sah yang belum dilunasi;

2) Terdapat surat penagihan dan telah dilaksanakan penagihan dan belum dilunasi.

Tagihan Penjualan Angsuran (TPA) dan Tuntutan Ganti Rugi (TGR) yang akan jatuh tempo 12 (dua belas) bulan setelah tanggal neraca disajikan sebagai Bagian Lancar TPA/TGR.

Nilai Persediaan dicatat berdasarkan hasil perhitungan fisik pada tanggal neraca dikalikan dengan :

1) harga perolehan terakhir, apabila diperoleh dengan pembelian;

2) harga pokok produksi terakhir apabila diperoleh dengan memproduksi sendiri;

3) harga wajar apabila diperoleh dengan cara tainnya sepert donasi.

b. Aset Tetap

Aset tetap mencakup seluruh aset berwujud yang mempunyai masa manfaat lebih dari 12 (dua belas) bulan untuk digunakan dalam kegiatan pemerintah daerah atau dimanfaatkan oleh masyarakat umum.

Nilai Aset tetap disajikan berdasarkan harga perolehan atau harga wajar.

Pengakuan aset tetap didasarkan pada nilai satuan minimum kapitalisasi sebagaimana diatur pada Peraturan Bupati Kapuas Nomor 30 Tahun 2014 tentang Kebijakan Akuntansi Pemerintah Kabupaten Kapuas. Pengeluaran yang tidak tercakup dalam batasan nilai minimum kapitalisasi, diperlakukan sebagai biaya kecuali pengeluaran untuk tanah, jalan/irigasi/jaringan, dan aset tetap lainnya berupa barang bercorak kesenian/kebudayaan.

c. Aset Lainnya

Aset Lainnya merupakan aset pemerintah daerah yang tidak dapat diklasifikasikan sebagai aset lancar, investasi jangka panjang, aset tetap dan dana cadangan.

Tagihan penjualan angsuran menggambarkan jumlah yang dapat diterima dari penjualan asset pemerintah daerah secara angsuran kepada pegawai pemerintah daerah. Contoh tagihan penjualan angsuran antara lain adalah penjualan rumah dinas dan penjualan kendaraan dinas.

Tuntutan Perbendaharaan (TP) merupakan suatu proses yang dilakukan terhadap bendahara dengan tujuan untuk menuntut penggantian atas suatu kerugian yang diderita oleh Pemda sebagai akibat langsung ataupun tidak langsung dari suatu perbuatan melanggar hukum yang dilakukan oleh bendahara tersebut atau kelalaian dalam pelaksanaan tugas kewajibannya.

1) Kemitraan adalah perjanjian antara dua pihak atau lebih yang mempunyai komitmen untuk melaksanakan kegiatan yang dikendalikan bersama dengan menggunakan asset dan/atau hak usaha yang dimiliki.

2) Aset tidak berwujud adalah asset tetap yang secara fisik tidak dapat dinyatakan atau tidak mempunyai wujud fisik serta dimiliki untuk digunakan dalam menghasilkan barang atau jasa atau digunakan untuk tujuan lainnya termasuk hak atas kekayaan intelektual.

3) Aset Lain-lain berupa asset tetap pemerintah yang dihentikan dari penggunaan aktif pemerintah daerah karena hilang atau rusak berat sehingga tidak dapat dimanfaatkan lagi tetapi belum dihapuskan, atau asset tetap yang dipinjam pakai kepada unit pemerintah yang lain, atau asset yang telah diserahkan ke pihak lain tetapi belum ada dokumen hibah atau serah terima atau dokumen sejenisnya.

6. Kewajiban

Kewajiban adalah utang yang timbul dari peristiwa masa lalu yang penyelesaiannya mengakibatkan aliran keluar sumber daya ekonomi pemerintah daerah.

Kewajiban pemerintah diklasifikasikan kedalam kewajiban jangka pendek dan kewajiban jangka panjang. 
a. Kewajiban Jangka Pendek

Suatu kewajiban diklasifikasikan sebagai kewajiban jangka pendek jika diharapkan untuk dibayar atau jatuh tempo dalam waktu dua belas bulan setelah tanggal pelaporan.

Kewajiban jangka pendek meliputi Utang Kepada Pihak Ketiga, Utang Bunga, Bagian Lancar Utang Jangka Panjang, Pendapatan Diterima di Muka, Utang Beban, dan Utang Jangka Pendek Lainnya.

b. Kewajiban Jangka Panjang

Kewajiban diklasifikasikan sebagai kewajlban jangka panjang jika diharapkan untuk dibayar atau jatuh tempo dalam waktu lebih dari dua belas bulan setelah tanggal pelaporan.

c. Kewajiban dicatat sebesar nilai nominal

7. Ekuitas

Ekuitas merupakan selisih antara aset dengan kewajiban dalam satu periode. Pengungkapan lebih lanjut dari ekuitas disajikan dalam Laporan Perubahan Ekuitas.

8. Penyisihan Piutang Tidak Tertagih

Penyisihan Piutang Tidak Tertagih adalah adalah taksiran nilai piutang yang kemungkinan tidak dapat diterima pembayarannya dimasa akan datang dari seseorang dan/atau korporasi dan/atau entitas lain.

Kualitas masing-masing piutang didasarkan atas empat kriteria kondisi yaitu lancar, kurang lancar, diragukan dan macet sesuai dengan Peraturan Bupati Kapuas Nomor 30 Tahun 2014 tentang Kebijakan Akuntansi Pemerintah Kabupaten Kapuas. Dengan besaran penyisihan piutang sebagai berikut :

\section{Tabel Besaran Penyisihan Piutang}

\begin{tabular}{lc}
\hline Kualitas Piutang & $\begin{array}{c}\text { Taksiran Piutang } \\
\text { Tak Tertagih }\end{array}$ \\
\hline Lancar & $0.5 \%$ \\
\hline Kurang Lancar & $10 \%$ \\
\hline Diragukan & $50 \%$ \\
\hline Macet & $100 \%$ \\
\hline
\end{tabular}

Sumber : Peraturan Bupati Kapuas Nomor 30 Tahun 2014

9. Penyusunan Aset Tetap

a. Penyusunan aset tetap adalah alokasi yang sismatis atas nilai suatu aset tetap yang dapat disusutkan (depreciable assets) selama masa manfaat asset tetap yang bersangkutan. Kebijakan penyusutan aset tetap didasarkan pada Peraturan Bupati Kapuas Nomor 30 Tahun 2014 tentang
Kebijakan

Akuntansi

Pemerintah

Kabupaten Kapuas.

b. Penyusutan aset tetap tidak dilakukan terhadap :

1) Tanah

2) Konstruksi dalam Pengerjaan (KDP)

3) Aset Tetap Tetap lainnya seperti buku, terbitan, barang-barang perpustakaan, barang bercorak kesenian/kebudayaan, alat olahraga, hewan ternak, dan tanaman.

c. Penghitungan dan Pencatatan Penyusutan Aset Tetap dilakukan setiap akhir tahun tanpa memperhitungkan adanya nilai residu.

d. Penyusutan Aset Tetap dilakukan dengan menggunakan metode garis lurus yaitu dengan mengalokasikan nilai yang dapat disusutkan dari Aset Tetap secara merata setiap akhir tahun selama Masa Manfaat.

e. Masa Manfaat Aset Tetap ditentukan dengan berpedoman Peraturan Bupati Kapuas Nomor 30 Tahun 2014 tentang Kebijakan Akuntansi Pemerintah Kabupaten Kapuas. Secara umum tabel masa manfaat adalah sebagai berikut :

Tabel Penggolongan Masa Manfaat Aset Tetap

\begin{tabular}{cc}
\hline Kelompok Aset Tetap & Masa Manfaat \\
\hline Peralatan dan Mesin & 2 s.d. 20 tahun \\
\hline Gedung dan Bangunan & 5 s.d.50 tahun \\
\hline $\begin{array}{c}\text { Jalan, Jaringan dan } \\
\text { Irigasi }\end{array}$ & 10s.d 40 tahun \\
\hline
\end{tabular}

Sumber : Peraturan Bupati Kapuas Nomor 30 Tahun 2014

10. Implementasi Akuntansi Berbasis Akrual Pertama Kali

Mulai tahun 2015 Pemerintah mengimplementasikan akuntansi berbasis akrual sesuai dengan amanat PP No. 71 Tahun 2010 tentang Standar Akuntansi Pemerintahan. Implementasi tersebut memberikan pengaruh pada beberapa hal dalam penyajian laporan keuangan. Pertama, Pos-pos ekuitas dana pada neraca per 31 Desember 2014 yang berbasis cash toward accrual direklasifikasi menjadi ekuitas sesuai dengan akuntansi berbasis akrual. Kedua, keterbandingan penyajan akun-akun tahun berjalan dengan tahun sebelumnya dalam Laporan Operasional dan Laporan Perubahan Ekuitas tidak dapat dipenuhi. Hal ini diakibatkan oleh penyusunan dan penyajian akuntansi berbasis akrual pertama kali mulai dilaksanakan tahun 2015. 
Prosedur Pengelolaan Keuangan Satuan Kerja Perangkat Daerah

1. Prosedur Pengajuan Dana

a. Surat Penyedia Dana (SPD)

SPD adalah dokumen yang menyatakan tersedianya dana untuk melaksanakan kegiatan sebagai dasar penerbitan SPP (Permendagri Nomor 13 Tahun 2006). SPD digunakan untuk menyediakan dana bagi tiap-tiap SKPD dalam periode waktu tertentu.

b. Surat Permintaan Pembayaran (SPP)

SPP adalah dokumen yang diterbitkan oleh pejabat yang bertanggung jawab atas pelaksanaan kegiatan/bendahara pengeluaran untuk mengajukan permintaan pembayaran (Permendagri Nomor 13Tahun 2006).

SPP memiliki 4 jenis, yang terdiri dari (Permendagri Nomor 13 Tahun 2006) :

1) SPP Uang Persediaan (SPP-UP) SPP-UP adalah dokumen yang diajukan oleh bendahara pengeluaran untuk permintaan uang muka kerja yang bersifat pengisian kembali (revolving) yang tidak dapat dilakukan dengan pembayaran langsung.

2) SPP Ganti Uang (SPP-GU)

SPP-GU adalah dokumen yang diajukan oleh bendahara pengeluaran untuk permintaan pengganti uang persediaan yang tidak dapat dilakukan dengan pembayaran langsung.

3) SPP Tambahan Uang (SPP-TU)

SPP-TU adalah dokumen yang diajukan oleh bendahara pengeluaran untuk permintaan tambahan uang persediaan guna melaksanakan kegiatan SKPD yang bersifat mendesak dan tidak dapat digunakan untuk pembayaran langsung dan uang persediaan.

4) SPP Langsung (SPP-LS)

SPP-LS adalah dokumen yang diajukan oleh bendahara pengeluaran untuk permintaan pembayaran langsung kepada pihak ketiga atas dasar perjanjian kontrak kerja atau surat perintah kerja lainnya dan pembayaran gaji dengan jumlah, penerima, peruntukan, dan waktu pembayaran tertentu yang dokumennya disiapkan oleh PPTK.

c. Surat Perintah Membayar (SPM)

SPM adalah dokumen yang digunakan/diterbitkan oleh pengguna anggaran/kuasa pengguna anggaran untuk penerbitan SP2D atas beban pengeluaran DPA-SKPD (Permendagri Nomor 13 Tahun 2006).

SPM juga dibedakan menjadi 4 (empat) sesuai dengan jenis SPPnya, yaitu (Permendagri Nomor 13 Tahun 2006) :

1) Surat Perintah Membayar Uang Persediaan (SPM-UP)

SPM-UP adalah dokumen yang diterbitkan oleh pengguna anggaran/kuasa pengguna anggaran untuk penerbitan SP2D atas beban beban pengeluaran DPA-SKPD yang dipergunakan sebagai uang persediaan untuk mendanai kegiatan.

2) Surat Perintah Membayar Ganti Uang (SPM-GU)

SPM-GU adalah dokumen yang diterbitkan oleh pengguna anggaran/kuasa pengguna anggaran untuk penerbitan SP2D atas beban pengeluaran DPA-SKPD yang dananya dipergunakan untuk mengganti uang persediaan yang telah dibelanjakan.

3) Surat Perintah Membayar Tambahan Uang (SPM-TU)

SPM-TU adalah dokumen yang diterbitkan oleh pengguna anggaran/kuasa pengguna anggaran untuk penerbitan SP2D atas beban pengeluaran DPA-SKPD, karena kebutuhan dananya melebihi dari jumlah batas pagu uang persediaan yang telah ditetapkan sesuai dengan ketentuan.

4) Surat Perintah Membayar Langsung (SPM-LS)

SPM-LS adalah dokumen yang diterbitkan oleh pengguna anggaran/kuasa pengguna anggaran untuk penerbitan SP2D atas beban pengeluaran DPA-SKPD kepada pihak ketiga.

d. Surat Perintah Pencairan Dana (SP2D) SP2D adalah dokumen yang digunakan sebagai dasar pencairan dana yang diterbitkan oleh BUD berdasarkan SPM (Permendagri Nomor 13 Tahun 2006). SP2D dapat diterbitkan jika :

1) Pengeluaran yang diminta tidak melebihi pagu anggaran yang tersedia

2) Didukung dengan kelengkapan dokumen sesuai peraturan perundangan 


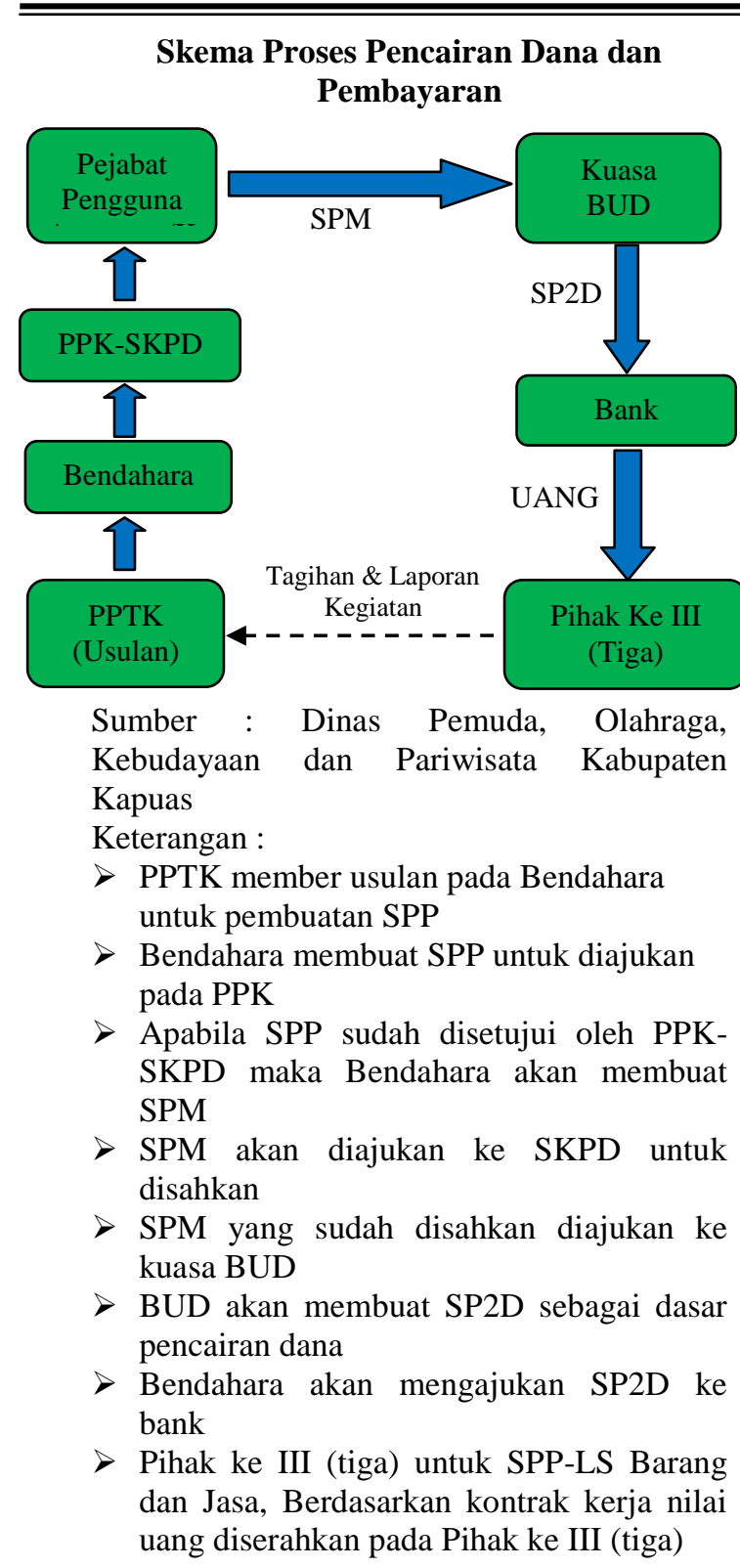

\section{Surat Pertanggungjawaban (SPJ) Pengeluaran}

SPJ merupakan dokumen yang menjelaskan penggunaan dari dana-dana yang dikelola oleh Bendahara. Secara administratif, bendahara pengeluaran wajib mempertanggungjawabkan penggunaan uang UP/GU/TU kepada kepala SKPD melalui PPK-SKPD paling lambat tanggal 10 bulan berikutnya.

Dalam mempertanggungjawabkan pengelolaan uang persediaan, dokumen laporan pertanggungjawaban yang disampaikan mencakup (Hariadi dkk, 2010) :

1. Buku kas umum pengeluaran

2. Ringkasan pengeluaran per perincian obyek

3. Bukti atas penyetoran $\mathrm{PPN} / \mathrm{PPh}$ ke kas negara

\section{PENUTUP}

\section{Kesimpulan}

Berdasarkan hasil penelitian yang sudah dilakukan, akhirnya penulis dapat menarik beberapa kesimpulan sebagai berikut:

1. Dinas Pemuda, Olahraga, Kebudayaan dan Pariwisata Kabupaten Kapuas telah memiliki prosedur pengelolaan keuangan sebagai pedoman yang mengatur tentang proses pengelolaan keuangan yang mencakup seluruh aspek keuangan yang dikelola oleh Dinas Kebudayaan, Kepemudaan dan Olahraga Kabupaten Kapuas.

2. Dalam prosedur pengelolaan keuangan yang dimiliki oleh Dinas Pemuda, Olahraga, Kebudayaan dan Pariwisata Kabupaten Kapuas telah memenuhi ketentuan pemerintah yang diatur dalam Peraturan Menteri Dalam Negeri Nomor: 13 Tahun 2006 Tentang Pedoman Pengelolaan Keuangan Daerah. Ketentuan tersebut menyangkut:

a. Prosedur Penerimaan dan Pengeluaran Kas pada SKPD

b. Sisten akuntansi pemerintah daerah meliputi serangkaian prosedur mulai dari proses pengumpulan data, pencatatan, pengikhtisaran, sampai dengan pelaporan keuangan

c. Pelaporan menyusun laporan keuangan meliputi: Laporan Realisasi Anggaran, Neraca, Laporan Operasional dan Laporan Perubahan Ekuitas.

\section{Saran}

Saran-saran yang dapat penulis berikan sehubungan dengan penelitian ini adalah:

1. Serangkaian prosedur mulai dari proses pengumpulan data, pencatatan, pengikhtisaran, sampai dengan pelaporan keuangan dalam rangka pertanggungjawaban pelaksanaan APBD hendaknya dapat dilakukan menggunakan aplikasi komputer.

2. Hendaknya Dinas Pemuda, Olahraga, Kebudayaan dan Pariwisata Kabupaten Kapuas dapat menyediakan sumber daya manusia yang berkompeten di bidang akuntansi Pemerintahan dengan mengikuti seminar dan pelatihan tentang penerapan SAP.

\section{DAFTAR PUSTAKA}

Abdul Halim. 2007. Akuntansi Sektor Publik Akuntansi Keuangan Daerah. Jakarta: Salemba Empat.

Ali, Muhammad. 2000. Penelitian Pendidikan Prosedur Dan Strategi.

Bandung: 
Ardiyos, 2004.Kamus Besar Akuntansi. Jakarta: Citra Harta Prima.

Azhar Susanto. 2004. Sistem Informasi Akuntansi Edisi Pertama. Lingga Jaya. Bandung.

Chabib, Soleh dan Rochmansjah, Heru. 2010. Pengelolaan Keuangan dan Aset

Daerah. Bandung : Fokusmedia

Hasiara, La Ode. 2009. Pemahaman Akuntansi Anggaran Badan Pengelola Keuangan dan Aset Daerah di Kabupaten Buton. Jurnal Ekonomi dan Bisnis. Tahun 14, Nomor 2, Juli 2009.

Indriantoro, Nur., Bambang Supomo, 2009. Metodologi Penelitian Bisnis untuk Akuntansi dan Manajemen, Edisi Pertama. Yogyakarta : BPFE Yogyakarta.

M. Nafarin, 2004. Penganggaran Perusahaan . Penerbit Salemba 4. Jakarta.

Mulyadi. 2013. Sistem Akuntansi. Jakarta: Salemba Empat
Peraturan Bupati Kapuas No. 148 Tahun 2008 tentang tugas dan fungsi Dinas Pemuda, Olahraga, Kebudayaan dan Pariwisata Kabupaten Kapuas.

Peraturan Menteri Dalam Negeri Nomor 13 Tahun 2006, Peraturan Menteri Dalam Negeri Nomor 59 Tahun 2007 yang mengatur tentang Pedoman Pengelolaan Keuangan Daerah dan Untuk penatausahaan keuangan daerah diatur oleh Peraturan Menteri Dalam Negeri Nomor 55 Tahun 2008.

Peraturan Pemerintah Nomor 24 Tahun 2004, Tentang Standar Akuntansi Pemerintahan

Peraturan pemerintah Republik Indonesia Nomor 71 Tahun 2010, tentang Standar Akuntansi Pemerintahan

\section{Profil Penulis :}

Vivi Pancasari Kusumawardani, SE., M. Si, Dosen Pada Sekolah Tinggi Ilmu Ekonomi (STIE) YBPK Palangkaraya Program Studi Akuntansi. 